interior of the earth from the very first, and that it simply makes. its escape at a tremendous pressure whenever a way is opened for it. through the solid crust.

O. Fisher.

HaRtTon.

March 5, 1901.

NAMES FOR BRITISH ICE-SHEETS.

Srr,-May I suggest to Mr. Lamplugh that to propose names for British Ice-sheets before proving that they have existed is rather like counting chickens before they are hatched. At present we know neither the ancient extent of land-ice in our Island, nor in all. cases what are indisputable traces of it. Where faith is strong this, no donbt, seems a detail, but to sceptics it appears important.

If, however, we admit that there was an East British Ice-sheet, "maintained and augmented principally by the snowfall upon its own surface," how are we to explain the presence of Scandinavian rocks at Cromer and other places on our East Coast? Of that icesheet the Dogger Bank would be centre and highest part. This tract is crossed (a little north of its centre) by a line drawn from Flamborough Head to the Naze of Norway. Over an area measuring. about 70 miles from east to west, and 12 miles in the opposite direction, it rises above the ten-fathom contour-line (the minimum depth being 7 fathoms). The twenty-fathom line is very near to the other one at the south-west end, but then recedes from it so as to enclose a long bank which stretches in a north-easterly direction, almost half-way across the North Sea, and the thirty-fathom line on the northern side extends from the Yorkshire coast to Jutland. North and north-west of this limit are soundings down to 49 fathoms, and those over 40 fathoms are rather common. In the great channel off the south-west of Norway they are often over 200 fathous (for particulars see this Magazine, 1899, p. 282). Thus the ice of the Dogger-fjeld (would not that have been a better name?) must havo descended from its central plateau down slopes about 250 feet in vertical height on the north and north-west, and about half that amount down those from the south-west to the south-east. This mass of ice flowing outwards towards nearly all points of the compass, and buttressed on the western side by the Caledonian ice, which it would try to 'shoulder' in that direction, would surely defend our shores from the intoads of the Scandinavian ice-sheet, however nimbly it night climb the steep slope of the above-mentioned channel. Is it, then, a mistake to identify Scandinavian rocks in East Anglia; for if the Dogger-fjeld existed they could not bave travelled on floating ice?

T. G. Bonney.

\title{
CONCRETIONS OF CALCITE IN MAGNESIAN LIMESTONE.
}

SrR,-The well-known globular concretions from the Magnesian Limestone of Durham occur in many collections under the name of 'dolumite' or 'magnesian limestone.' Professor Garwood, however, effectually showed (Groc. MAG., 1891, p. 436) that these concretions are due to the crystallization of calcite in a ground of 


\section{Correspondence-Prof. G. A. J. Cole-A. Strahan.}

magnesian limestone, and that the 5 to 15 per cent. of magnesium carbonate contained in them is a mere impurity, when compared with the 30 per cent. in the matrix from which they have arisen. It is interesting to come across a similar statement made in 1817, though we waited long for Professor Garwood's numerical proofs, and for a complete account of the wode of origin of the concretions. Mr. N. J. Winch (Transactions of the Geological Society of London, vol. iv, p. 9) remarks that "botryoidal masses of fetid limestone devoid of magnesia, in balls varying from the size of a pea to two feet in diameter, imbedded in a soft, marly, magnesian limestone, are found at Hartlepool, etc." Winch had given a specimen some twelve years before to James Sowerby ("British Mineralogy," table 38), and the passage above quoted was incorporated by Conybeare \& Phillips in their "Geology of England and Wales," 1822, p. $306 . \quad$ Grenvilue A. J. Cole.

Dublin, Afarch 1, 1901.

SUCCESSION OF STRATA IN THE YOREDALE ROCKS.

SIR,-Mr. Dakyns is right in his criticism on the succession I quoted for the Yoredale strata of the Yore Valley. It is true that the sequence, though there are many exceptions, is usually-

\section{Shale. \\ Limestone. \\ Sandstone.}

But this may be put in another way. The series as a whole is made up of repetitions of this threefold cycle, and may with equal correctness be regarded as consisting of repetitions of the cycle-

\section{Sandstone. \\ Shale. \\ Limestone.}

We have, therefore, the same evidence of intermittent and more or less rhythmic sedimentation which I claimed for the Coal-measures. But there is this difference, that whereas in the Yoredales the cycle commences with inactivity (limestone) and proceeds to rapid sedimentation (sandstone), in the Coal-measures it commences with activity (sandstones and conglomerates) and proceeds to stagnation (coal-seams), the order being-

Coal.

Shale.

Sandstone and conglomerate.

Both formations result from rapid sedimentation over a subsiding area, but whereas the Coal-measures are essentially estuarine, the Yoredale rocks of the type developed in the Yore Valley bear every sign of having been laid down in open sea; the one was a product of the shallowest water, the other of comparatively deep water. Herein probably lies the explanation of the reversal of order of events.

I am obliged to Mr. Dakyns for the correction.

March 6, 1901 .

\section{A. Strahan.}

